\title{
Simultaneous Presentation of Parvovirus B19 Infection and Systemic Lupus Erythematosus in a Patient: Description and Review of the Literature
}

\author{
Paul Chabert, Hatem Kallel \\ Intensive Care Unit, Cayenne General Hospital, Cayenne, French Guiana
}

Received: $15 / 05 / 2020$

Accepted: $21 / 05 / 2020$

Published: $19 / 10 / 2020$

\begin{abstract}
How to cite this article: Chabert P, Kallel H. Simultaneous presentation of Parvovirus B19 infection and systemic lupus erythematosus in a a patient: description and review of the literature. EJCRIM 2020;7: doi:10.12890/2020_001729.
\end{abstract}

Conflicts of Interests: The Authors declare that there are no competing interests.

This article is licensed under a Commons Attribution Non-Commercial 4.0 License

\section{ABSTRACT}

We present the case of a 25 -year-old woman without medical history, presenting with acute respiratory failure needing mechanical ventilation. Aetiologic screening showed PVB19 primary infection and concomitant SLE flare-up. We discuss the causative interactions between PVB19 and SLE in the pathogenesis of the disease. Difficulty diagnosing inaugural SLE flare-up concomitant with PVB19 infection can lead to delayed diagnosis and treatment. Inversely, overtreating a SLE-mimicking PVB19 infection with immunosuppressive agents can be highly detrimental.

\section{LEARNING POINTS}

- The differential diagnosis between parvovirus B19 primary infection and systemic lupus erythematosus flare-up can be difficult.

- Parvovirus B19 primary infection can elicit authentic severe systemic lupus erythematosus flare-up that requires urgent immunosuppressive therapy.

- Parvovirus B19 primary infection can also mimic systemic lupus erythematosus.

\section{KEYWORDS}

Parvovirus B19, systemic lupus erythematosus, acute respiratory distress syndrome, critical care

\section{INTRODUCTION}

Parvovirus B19 (PVB19) is a DNA virus. Its transient replication is often asymptomatic, or can classically cause erythema infectiosum, acute polyarthritis, anaemia and aplastic crisis. Systemic lupus erythematosus (SLE) is an auto-immune disease, it can cause multi-organ flare-up including skin eruption, arthritis, haemolysis, renal, heart and lung involvement. Infectious agents are proposed to act as triggers for autoimmunity ("viral hypothesis" ${ }^{[1]}$ ). PVB19 manifestations sometimes show intriguing similarities to SLE ${ }^{[2,3]}$. We describe the case of a 25-yearold critically ill woman presenting PVB19 primary infection and concomitant inaugural SLE flare-up. We review the literature on the links between PVB19 and SLE and discuss whether PVB19 can elicit SLE.

\section{CASE DESCRIPTION}

A 25-year-old woman was admitted to our intensive care unit, for febrile acute respiratory failure, polyarthralgia and rash. She had no medical history and no anterior apparent SLE-compatible symptoms. The first symptoms appeared 2 weeks earlier with febrile diffuse arthromyalgia and cough. Clinical findings at admission showed: sinus tachycardia without murmur, bilateral crackles, oxygen desaturation, no joint swelling, malar macular rash, digital purpura and buccal ulcerations. Chest CT showed bilateral interstitial infiltration, with alveolar 
opacities and bilateral pleural effusion (Fig. 1). Initial echocardiography found normal left ventricular systolic function, with little pericardial effusion. Laboratory findings are reported in Table 1. The patient received empiric antibiotherapy with cefotaxime and levofloxacin and diuretic therapy. Despite this, the respiratory state worsened and the patient required invasive protective mechanical ventilation. We noted transitory deterioration of left ventricular global systolic function. She received corticosteroid boluses, intravenous immunoglobulins and cyclophosphamide. In a second phase, while thrombocytopenia persisted, haptoglobin plummeted, reticulocytes increased and schistocytes reached $4.7 \%$. She developed a transient moderate acute kidney injury. Renal biopsy objectified class II mesangial proliferative lupus glomerulonephritis, and capillary thrombi consistent with thrombotic microangiopathy. ADAMTS13 activity was normal. All abnormalities scaled back without plasma exchange. The patient was weaned from mechanical ventilation and discharged from hospital. Long-term follow-up confirmed the persistence of biological auto-immunity and the diagnosis of SLE, its clinical course being now stabilized with oral corticosteroid and immunosuppressive drugs.

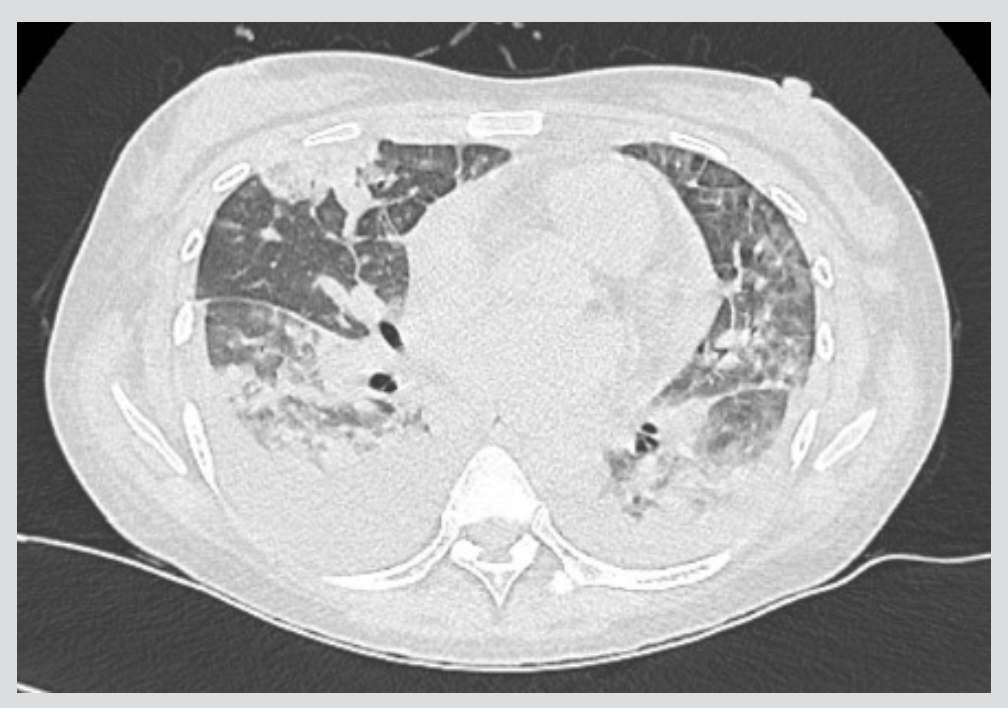

Figure 1. Chest CT scan

\section{DISCUSSION}

Our patient was a young woman presenting with PVB19 primary infection and concomitant inaugural SLE flare-up. We discuss the roles of both processes in the pathogenesis of her clinical presentation, and causative interactions between PVB19 and SLE.

PVB19 often triggers antinuclear antibody production ${ }^{[4]}$; this is usually transient ${ }^{[5]}$, but is sometimes persistent ${ }^{[3]}$. Indeed, the presence of antiphospholipid antibodies following PVB19 primary infection is frequently observed ${ }^{[3,6]}$ and titres of anti-PVB19 antibodies and PVB19 viraemia are higher in SLE patients ${ }^{[7]}$. Hession et al. ${ }^{[8]}$ reported that acutely PVB19-infected patients with high titres of antinuclear antibodies presented a high risk of persistent SLE. Conversely, Speyer et al. ${ }^{[9]}$ found no association between PVB19 infection and long-term inflammatory joint disease. Thus far, the literature lacks epidemiological evidence of an association between SLE and PVB19 [10, 11].

The literature includes many cases of PVB19 infection mimicking or triggering SLE flare-up ${ }^{[1]}$ with various atypical clinical pictures ${ }^{[3]}$. SLE 1997 American College of Rheumatology diagnosis criteria ${ }^{[12]}$ include 5 clinical items that can overlap with PVB19 infection (fever, rash, arthritis, anaemia and thrombocytopenia). In our patient, these 5 items were present and could be attributed to both pathological processes. Usual haematological findings encountered in PVB19 infection result from erythroblastopenia. In our patient, the initial anaemia was aregenerative, and thus, attributable to PVB19. PVB19 is probably involved in SLE-associated dilated cardiomyopathy [13, 14], through a mechanism implicating IL-17. Our patient presented transient left ventricular systolic dysfunction. It remains uncertain whether this abnormality was caused by PVB19 or SLE, or if it had another origin such as stress cardiomyopathy. PVB19-induced nephropathy is multifactorial ${ }^{[15,16]}$ but is often post-infectious glomerulonephritis. Pathological findings in our patient were consistent with SLE glomerulonephritis. In our patient, dermatologic and rheumatologic initial manifestations could be attributed either to SLE or to PVB19. Nevertheless, digital purpura suggests SLE vasculitis or thrombotic microangiopathy. Alveolar haemorrhage can be linked to specific SLE pulmonary end-organ damage, to an undiagnosed infectious pneumonia, to cardiogenic pulmonary oedema or to severe thrombocytopenia. The proposed mechanisms for PVB19-triggered SLE flare-up include molecular mimicry and epitope spreading. Th1 cytokines are increased during PVB19 infection ${ }^{[17]}$ with sustained elevation after viral clearance. These could be involved in SLE-mimicking symptoms of PVB19 infection ${ }^{[18]}$. The same Th1 cytokines are implicated in SLE pathogenesis ${ }^{[19]}$. 


\begin{tabular}{|c|c|}
\hline Analysis & $\begin{array}{l}\text { Results } \\
\text { (normal range) }\end{array}$ \\
\hline Haemoglobin & $6 \mathrm{~g} / \mathrm{dl}(11.5-17.5)$ \\
\hline $\begin{array}{l}\text { - Leucocytes } \\
\text { - Neutrophils } \\
\text { - Lymphocytes }\end{array}$ & $\begin{array}{l}3.5 \mathrm{G} / \mathrm{l}(3.8-11) \\
2.42 \mathrm{G} / \mathrm{l}(1.4-7.7) \\
0.92 \mathrm{G} / \mathrm{l}(1-4.8)\end{array}$ \\
\hline Platelets & $9 \mathrm{G} / \mathrm{l}(150-445)$ \\
\hline Mean corpuscular volume & $88 f 1(76-96)$ \\
\hline Reticulocyte count & $43 \mathrm{G} / \mathrm{l}$ \\
\hline $\mathrm{LDH}$ & 442 IU/I (135-214) \\
\hline Bilirubinaemia & $9.3 \mu \mathrm{mol} / \mathrm{l}(0-21)$ \\
\hline Haptoglobin & $0.72 \mathrm{~g} / \mathrm{l}(0.3-2.1)$ \\
\hline B9 & $5.7 \mathrm{nmol} / \mathrm{l}(5-34)$ \\
\hline B12 & $119 \mathrm{pmol} / \mathrm{l}(100-900)$ \\
\hline Ferritinaemia & $535 \mu \mathrm{g} / \mathrm{l}(10-125)$ \\
\hline Creatininaemia & $36 \mu \mathrm{mol} / \mathrm{l}(45-84)$ \\
\hline Uraemia & $3 \mathrm{mmol} / \mathrm{l}(0-8.1)$ \\
\hline CRP & $65 \mathrm{mg} / \mathrm{l}(0-5)$ \\
\hline Troponin & $0.05 \mu \mathrm{g} / \mathrm{l}(0-0.014)$ \\
\hline NT-proBNP & $4,755 \mathrm{ng} / \mathrm{l}(0-300)$ \\
\hline Proteinuria & $1.68 \mathrm{~g} / 24 \mathrm{~h}$ \\
\hline Urinary sediment & Haematuria \\
\hline Alveolar fluid cytology & $\begin{array}{l}\text { Alveolar haemorrhage } \\
\text { (Golde score >100) }\end{array}$ \\
\hline Dengue PCR (blood) & Negative \\
\hline Influenza PCR (nasal smear) & Negative \\
\hline Chikungunya PCR (blood) & Negative \\
\hline HIV & Negative \\
\hline Hepatitis B, hepatitis C & Negative \\
\hline CMV & Negative \\
\hline Plasmodium (thick and thin smears) & Negative \\
\hline Coxiella burnetii (serology) & Negative \\
\hline Toxoplasma gondii (serology, PCR) & Negative \\
\hline Mycoplasma pneumoniae (serology) & Negative \\
\hline Leptospira (serology, PCR) & Negative \\
\hline Legionella (urinary antigens) & Negative \\
\hline Bacteriological blood cultures & Negative \\
\hline $\begin{array}{l}\text { Bacteriological culture of tracheal } \\
\text { aspirations and alveolar fluid }\end{array}$ & Negative \\
\hline
\end{tabular}

\begin{tabular}{|c|c|}
\hline Analysis & $\begin{array}{c}\text { Results } \\
\text { (normal range) }\end{array}$ \\
\hline PVB19 IgG & $33 \mathrm{IU} / \mathrm{I}(\mathrm{N}<0.8)$ \\
\hline PVB19 IgM & $3.3 \mathrm{IU} / \mathrm{I}(\mathrm{N}<0.7)$ \\
\hline PVB19 PCR (blood) & Positive \\
\hline Anti-CCP & Negative \\
\hline Rheumatoid factor & $5.5 \mathrm{IU} / \mathrm{I}(0-5)$ \\
\hline Antinuclear antibodies (IFA) & $1 / 640$ \\
\hline Anti-ENA & Anti-Scl-70 >320 IU/ml \\
\hline Cryoglobulinaemia & Positive, type III \\
\hline Anti-double-stranded DNA & $>300 \mathrm{IU} / \mathrm{ml}$ \\
\hline $\begin{array}{l}\text { Complement } \mathrm{CH} 50 \\
-\mathrm{C} 3 \\
-\mathrm{C} 4\end{array}$ & $\begin{array}{l}\text { Hypocomplementaemia } \\
0.21(0.9-1.8) \\
<0.04(0.1-0.4)\end{array}$ \\
\hline Anticardiolipin IgM & Positive \\
\hline Antineutrophil cytoplasmic antibodies & Negative \\
\hline $\begin{array}{l}\text { Anti-glomerular basement membrane } \\
\text { antibodies }\end{array}$ & Negative \\
\hline C1 inhibitor & Normal \\
\hline
\end{tabular}

Lupus-prone mice treated with PVB19 proteins exhibited aggravated disease activity ${ }^{[20]}$. The production of antibodies with cross-reactivity against keratin, denatured DNA and cardiolipin was observed in these mice ${ }^{[21]}$. Meyer and others proposed that abnormal apoptosis triggered by PVB19 is responsible for production of autoantigens ${ }^{[22,23]}$. Pavlovic et al. ${ }^{[24]}$ proposed that hydrolytic anti-DNA antibodies may target either viral or host DNA. This would lead to cell death, exposure to apoptotic corpses and a break in immunotolerance.

\section{CONCLUSION}

Care should be taken when coming to a diagnosis of SLE during PVB19 infection. Our patient exhibited unquestionable SLE manifestations concomitant with PVB19 primary infection. Difficulty in diagnosing inaugural SLE flare-up concomitant with PVB19 infection can lead to delayed diagnosis. Inversely, overtreating an SLE-mimicking PVB19 infection is highly detrimental. 


\section{REFERENCES}

1. Ramos-Casals M, Cuadrado MJ, Alba P, Sanna G, Brito-Zerón P, Bertolaccini L, et al. Acute viral infections in patients with systemic lupus erythematosus: description of 23 cases and review of the literature. Medicine (Baltimore) 2008;87(6):311-318.

2. Cooray M, Manolakos JJ, Wright DS, Haider S, Patel A. Parvovirus infection mimicking systemic lupus erythematosus. CMAJ 2013;185(15):1342-1344.

3. Georges E, Rihova Z, Cmejla R, Decleire PY, Langen C. Parvovirus B19 induced lupus-like syndrome with nephritis. Acta Clin Belg 2016;71(6):423-425.

4. Soloninka CA, Anderson MJ, Laskin CA. Anti-DNA and antilymphocyte antibodies during acute infection with human parvovirus B19. J Rheumatol 1989;16(6):777-781.

5. Cugler T, Carvalho LM de, Facincani I, Yamamoto AY, Silva GEB, Costa RS, et al. Severe glomerulonephritis and encephalopathy associated with parvovirus B19 infection mimicking systemic lupus erythematosus. Scand J Rheumatol 2012;41(1):79-81.

6. Loizou S, Cazabon JK, Walport MJ, Tait D, So AK. Similarities of specificity and cofactor dependence in serum antiphospholipid antibodies from patients with human parvovirus B19 infection and from those with systemic lupus erythematosus. Arthritis Rheum 1997;40(1):103-108.

7. Valencia Pacheco G, Nakazawa Ueji YE, Rodríguez Dzul EA, Angulo Ramírez AV, López Villanueva RF, Quintal Ortiz IG, et al. Serological and molecular analysis of parvovirus B19 infection in Mayan women with systemic lupus erythematosus in Mexico. Colomb Med (Cali) 2017;48(3):105-112.

8. Hession MT, Au SC, Gottlieb AB. Parvovirus B19-associated systemic lupus erythematosus: clinical mimicry or autoimmune induction? J Rheumatol 2010;37(11):2430-2432.

9. Speyer I, Breedveld FC, Dijkmans BA. Human parvovirus B19 infection is not followed by inflammatory joint disease during long term follow-up. A retrospective study of 54 patients. Clin Exp Rheumatol 1998;16(5):576-578.

10. Bengtsson A. No serological indications that systemic lupus erythematosus is linked with exposure to human parvovirus B19. Ann Rheum Dis 2000;59(1):64-6.

11. Page C, François C, Goëb V, Duverlie G. Human parvovirus B19 and autoimmune diseases. Review of the literature and pathophysiological hypotheses. J Clin Virol 2015;72:6974.

12. Hochberg MC. Updating the American College of Rheumatology revised criteria for the classification of systemic lupus erythematosus. Arthritis Rheum 1997;40(9):1725.

13. Chen J, Zhang H, Chen P, Lin Q, Zhu X, Zhang L, et al. Correlation between systemic lupus erythematosus and cytomegalovirus infection detected by different methods. Clin Rheumatol 2015;34(4):691-698.

14. Chen DY, Chen YM, Tzang BS, Lan JL, Hsu TC. Th17-related cytokines in systemic lupus erythematosus patients with dilated cardiomyopathies: a possible linkage to parvovirus B19 infection. PLoS One 2014;9(12):e113889.

15. Kishi S, Yamada S, Kishi F, Shibata E, Matsuura M, Nagai K, et al. Acute glomerulonephritis in an immunocompetent elderly woman after contact with a child who had been diagnosed as erythema infectiosum. Intern Med 2012;51(16):2197-2201.

16. Waldman M, Kopp JB. Parvovirus B19 and the kidney. Clin J Am Soc Nephrol 2007;2 Suppl 1:S47-S56.

17. Isa A, Lundqvist A, Lindblom A, Tolfvenstam T, Broliden K. Cytokine responses in acute and persistent human parvovirus B19 infection. Clin Exp Immunol 2007;147(3):419425.

18. Park SJ, Kim JH, Ha TS, Shin Jl. Association of parvovirus B19 infection with systemic lupus erythematosus: role of Th1 predominance. J Rheumatol $2011 ; 38(6): 1221$.

19. Tokano Y, Morimoto S, Kaneko H, Amano H, Nozawa K, Takasaki Y, et al. Levels of IL-12 in the sera of patients with systemic lupus erythematosus (SLE)-relation to Th1- and Th2-derived cytokines. Clin Exp Immunol 1999;116(1):169-173.

20. Tzang BS, Lin TM, Tsai CC, Hsu JD, Yang LC, Hsu TC. Increased cardiac injury in NZB/W F1 mice received antibody against human parvovirus B19 VP1 unique region protein. Mol Immunol 2011;48(12-13):1518-1524.

21. Lunardi C, Tinazzi E, Bason C, Dolcino M, Corrocher R, Puccetti A. Human parvovirus B19 infection and autoimmunity. Autoimmun Rev 2008;8(2):116-120.

22. Thammasri K, Rauhamäki S, Wang L, Filippou A, Kivovich V, Marjomäki V, et al. Human parvovirus B19 induced apoptotic bodies contain altered self-antigens that are phagocytosed by antigen presenting cells. PLoS One 2013;8(6):e67179.

23. Meyer O. Parvovirus B19 and autoimmune diseases. Joint Bone Spine 2003;70(1):6-11.

24. Pavlovic M, Kats A, Cavallo M, Shoenfeld Y. Clinical and molecular evidence for association of SLE with parvovirus B19. Lupus 2010;19(7):783-792. 